\title{
The Importance of Insects in Agricultural Ecosystems
}

\author{
Astrid Jankielsohn \\ ARC-Small Grains, Bethlehem, Palestine \\ Email: jankielsohna@arc.agric.za
}

How to cite this paper: Jankielsohn, A. (2018) The Importance of Insects in Agricultural Ecosystems. Advances in Entomology, 6, 62-73.

https://doi.org/10.4236/ae.2018.62006

Received: January 30, 2018

Accepted: April 10, 2018

Published: April 13, 2018

Copyright (C) 2018 by author and Scientific Research Publishing Inc. This work is licensed under the Creative Commons Attribution International License (CC BY 4.0).

http://creativecommons.org/licenses/by/4.0/

\begin{abstract}
Sufficient food production for a growing human population has become an issue of global concern. Almost all of the world's fertile land is currently in use and arable land areas cannot be expanded significantly. The global challenge is to secure high and quality yields and to make agricultural production environmentally compatible. Insects have been hugely successful in terms of both species richness and abundance. Insects make up the most numerous group of organisms on earth, around $66 \%$ of all animal species, and being good dispersers and exploiters of virtually all types of organic matter, can be found almost everywhere, forming an important part of every ecosystem and are vital within our food supply chains performing valuable ecosystem services. Insects have been predominantly perceived as competitors in the race for survival. Herbivorous insects damage $18 \%$ of world agricultural production. Despite this damage less than 0.5 percentage of the total number of the known insect species are considered pests. Insect pests are created through the manipulation of habitats by humans, where crops are selected for larger size, higher yields, nutritious value, and are cultivated in monocultures for maximum production. This provides a highly favourable environment for the population increase of herbivorous insects. To ensure stable crop yields we need to change the management strategies of agroecosystems. We need to manage these systems in such a way that insects performing valuable ecosystem services are also incorporated into the system. This will ensure stable, resilient and sustainable systems in a constantly changing environment and will go a long way to ensure future food security. This paper examines the important role that insects generally play in ecosystems and how the services that insects provide can improve agricultural ecosystems.
\end{abstract}

\section{Keywords}

Insects, Biodiversity; Functional Diversity, Agro-Ecosystems, Food Security 


\section{Introduction}

Sufficient food production for a growing human population has become an issue of global concern. It is estimated that by 2050 the global population size will have increased by $46 \%$, requiring increased agricultural production to ensure food security [1]. The challenges we face are to produce food and ensure food security in an environment where insect and disease damage and climate change are major constraints [2] [3] [4]. The use of land for agricultural food production affects large parts of terrestrial area, whose contribution to biodiversity is essential for successful future conservation [5]. Almost all of the world's fertile land is currently in use and arable land areas cannot be expanded significantly. In addition to using large quantities of land, agriculture threatens the stability and survival of natural biodiversity more than any human activity in the world [6]. The clearing of natural ecosystems to increase food crops and livestock production, use of large quantities of water and application of agricultural chemicals are contributing to significant changes in ecological systems [7]. The global challenge is to secure high and quality yields and at the same time ensure that agricultural production is environmentally sustainable. To reach this goal we will have to reconsider the role of insects in our agricultural ecosystems. Insects, as drivers of ecosystem functions, play a major role in agro-ecology, the management of agricultural systems in an ecologically sound and sustainable way [8] by encouraging ecosystem services (ES) provided by beneficial organisms. Ecosystem services (ES) are the benefits that humans derive from ecosystems [9]. In terrestrial ecosystems insects play key ecological roles in diverse ecological processes such as nutrient cycling, seed dispersal, bioturbation [10] [11] [12], pollination [13] [14], and pest control [15] [16] [17] [18]. In conventional agriculture, production practices focus on few preferred species and their specific requirements, yet the potential services of many other species are ignored [19]. Agricultural production systems are intensified by increased use of external inputs to increase yield, but at the cost of biodiversity, causing ecosystems to become destabilized [20] [21]. Diversity is a central characteristic of natural ecosystems and facilitates these systems to be resilient and able to survive major changes. This biodiversity found in natural ecosystems can also be the key to sustainable agricultural production and food security. Agricultural systems cannot survive major disturbances because of a lack of diversity in these systems. Understanding the function of insects in ecosystems will enable us to recognize their importance in the sustainable functioning of our agricultural systems and their role in future food security.

\section{The Measurement of Biodiversity}

We do not know the exact number of all species on earth [22], but the estimated number of species is 5 - 15 million species [23]. Biodiversity is variation of life and refers to all species of plants, animals and microorganisms existing and interacting within an ecosystem. This biodiversity performs a variety of ecological 
services in an ecosystem, which support one another and work together to form a stable and sustainable ecosystem. Traditionally the determination of biodiversity was based on the number of species in an ecosystem, with ecosystems with a higher number of species being perceived as more stable and resilient. Biodiversity is, however, not just about numbers in an ecosystem, but also the particular traits contributed by various species. Traits are defined as physical or behavioural characteristics that evolve in response to competitive interactions and abiotic conditions [24]. Different species have different characteristics, measured in certain traits and it is these specific traits that contribute to ecosystem health and resilience. Traits will therefore influence survival, fitness and rates of resource processing, consequently influencing ecosystem services [19] [25]. Woodcock et al. [24] regards species richness as a simple descriptor of community structure, which takes no account of the range and value of behavioural or morphological species traits that contribute to the delivery of ecosystem services. Species identity alone cannot be used to predict the strength and type of ecological interactions of organisms without additional information about the trait and biology of the species [26]. Considering only the number of species therefore ignores any variation in ecological interactions with species and functional differences within species that can rival differences between species [27]. Functional diversity is also important in determining how organisms will cope with changes in the ecosystem and it is essential to consider interaction of these functions between different species.

The other variable important in determining biodiversity is size. Natural communities exhibit regular size-abundance relationships and body size is a key factor determining ecological interactions [28]. The diversity of resources used by an individual increases with the size of the particular individual [29]. Volker et al. [26] demonstrated that both body size and species identity is important in predicting how changes in community structure influence the functioning of natural ecosystems. The loss of both species and size classes will therefore have detrimental consequences for ecosystems.

When species go extinct locally, their unique traits are lost from the ecosystem and overall functional diversity will decline as a result, potentially impacting the delivery of vital ecosystem services [24]. When determining biodiversity it is therefore important to consider both size and function, as well as the interaction between the different species in an ecosystem.

\section{Contribution of Insects to Biodiversity}

Arthropods have existed for more than 400 million years and survived the Permian and Cretaceous mass extinctions [30]. Insects have been hugely successful in terms of both species richness and abundance and insects and terrestrial arthropods are seen to be the largest contributors to species richness [31] [32]. Insects account for approximately $66 \%$ of all known species [33], constituting more than three-quarters of today's global biodiversity [30]. There are about 1 
million species of known insects [33], but only around $7 \%-10 \%$ of insects are scientifically described [31]. Since many insect species are not yet identified, it is estimated that there could be around eight million species of insects on earth [34]. Stork et al. [32] estimates all insects to be around a mean of 5.5 million species and a range of $2.6-7.8$ million. The total number of insect individuals is estimated $10^{18}-10^{19}$ [35]. In terms of biomass insects also dominate with 150 to 1500 kilos of insects for each human being [35].

There are 39 insect orders, with the most speciose group represented by the Beetles (Order: Coleoptera). Beetles alone account for around $40 \%$ of all described arthropod species, with an estimate of 1.5 million beetle species [32]. The reason why there are so many species of beetles is reflected in the Jurassic origin of numerous modern lineages, high lineage survival, and diversification into a wide range of niches, including the utilization of all parts of plants [36] [37].

\section{Role of Insects in Ecosystems}

Biotic communities are vital for providing ecological functions and ecosystem services [38]. As a dominant form of animal biomass and life on earth, insects represent many different trophic niches and a wide range of ecological functions in their natural ecosystems, including herbivory, carnivory, and detritus feeding. Insects are abundant in all terrestrial ecosystems and display a wide variation among species in almost any aspect of their biology [39]. Because of the large numbers of insects and great intra-and interspecific variety the functional significance of insects is enormous [31] and the ecosystem services provided by insects vital. Insects are the key components in diverse ecosystems as major role players in functioning of ecosystem processes [30]. Since insects are mostly perceived as pests or potential pests, this ecological importance of insects often goes unnoticed. The main ecological functions of insects in ecosystems are ecosystem cycling, pollination, predation/parasitism, and decomposition:

\subsection{Ecosystem Cycling}

Insect herbivores change the quality, quantity, and timing of plant detrital inputs and can potentially have large effects on ecosystem cycling [40] [41]. Belovsky and Slade found that grasshopper herbivory increased plant abundance because of greater $\mathrm{N}$ availability [41]. Insect herbivores are therefore important drivers of ecosystem processes by transforming living plant biomass into frass, greenfall, and throughfall [42] and may drive a significant fraction of above-ground to belowground $\mathrm{N}$ and $\mathrm{P}$ fluxes across entire ecosystems [43].

\subsection{Pollination}

Over three quarters of wild flowering plant species in temperate regions need insects for pollination and about two thirds of all plant species rely on insects for pollination. The most important pollinators are bees, beetles, butterflies and flies [44]. Insects therefore contribute to plant diversity and affects animal biodiver- 
sity through pollination indirectly.

\subsection{Predation/Parasitism}

Occupying the higher trophic levels as secondary or tertiary consumers, predators and parasites help control the population increase of primary consumers or phytophagous organisms below a threshold. Herbivorous insects with the potential of becoming pests are under natural control by insect predators and parasitoids [45]. In the insect orders Odonata (dragon flies) and Neuroptera (lacewings and ant lions) all the insect species are predators, while a large percentage of species in the orders Hemiptera (bugs), Coleoptera (beetles), Diptera (flies) and Hymenoptera (wasps, bees and ants) are predators, either as larvae or in both larval and adult stages. There are various parisitoids in the order Hymenoptera that parasitizes either adults, larvae or eggs of other insects. For instance, Aphytis lingnanensis parasitizes scale insects, Aphelinus asychis, Aphelinus varipes, Diaeretiella rapae, Aphidius colemani, Aphidius, matricariae and Aphidius ervi parasitizes cereal aphids and Trichogramma parasitic wasps attack Lepidopteran eggs.

\subsection{Decomposition}

The decomposition of organic waste, such as dung and carrion is an important ecosystem process which is largely provided by insects. There are about 4000 documented dung beetle species which play an important role in the decomposition of manure. Dung beetles are principally important in the maintenance of pasture health by burying dung, which has the effect of removing surface wastes and recycling nutrients that can be used by plants. Negative environmental effects, such as loss of grass cover, growth of unpalatable grass, leaching of nutrients in surface rainwater runoff, and the buildup of large populations of dung-breeding flies, that resulted from a lack of dung beetles contributing the needed ecosystem function were seen in Australia before the introduction of dung beetles adapted to cattle dung [46]. Dung beetles contribute to soil health by increasing nitrogen, phosphorous, potassium, calcium and magnesium or total proteins content [47]. Dung beetles also contribute to the carbon cycle reducing GHG emissions by between $7 \%$ and $12 \%$ [12]. Beetle larvae, flies, ants and termites clean up dead plant matter and break it down for further decomposition by microbes. Ants and termites, the soil macrofauna in dry and hot regions, play an important role in the increase of mineral nitrogen in the soil [48].

Carrion provides food to a diverse community of insects with major roles for insect detritivores such as flies and beetles [49]. Calliphorid flies are the first to exploit cadavers and this is the start of a dynamic succession of arthropod species colonizing the cadaver, which can comprise 100 species from tens of insect families [50] [51]. It is, however, the function contributed by a specific species that determines the efficiency of the decomposition. Farwig et al. [50] found that decomposition rate of carrion is dependent on composition not abundance of 
the assemblages of insect scavengers.

\section{The Value of Non-Native Insect Species in Ecosystems}

Introduced species have the potential of becoming invasive and may prey on or outcompete indigenous species. Many non-native species, however, can also provide valuable ecosystem services [52]. With a constantly changing environment ecosystems need to change and adapt to survive. Non-native species can be seen as the pioneers and colonists in this constant renewal [53]. These species could come to fill important ecosystem functions, particularly in places where native species cannot survive as a result of environmental changes. Non-native species may contribute to ecosystem resilience by providing habitat, food, or trophic subsidies for native species, serving as catalysts for the restoration of native species, serving as substitutes for extinct ecosystem engineers, and providing important ecosystem services [54]. There are many success stories of non-native insect species providing vital ecosystem functions when introduced to new ecosystems. As far back as 1887 the cottony cushion scale, Icerya purchase, was successfully controlled by the release of the introduced coccinellid beetle Rodoliacardinalis [55]. Since then a total of 2627 introductions have resulted in satisfactory control against 172 pest species, the majority of which having a long lasting effect [56]. Dung beetles from Africa and Europe were screened and introduced into Australia to successfully decrease cattle dung in Australian pastures [57] [58].

\section{Insects in Agriculture}

For as long as humans practiced crop agriculture, pests have occurred on their crops and insects have been predominantly perceived as competitors in the race for survival. The insect-plant relationship is the dominant biotic interaction [31] and approximately $50 \%$ of insect species are herbivorous, with most herbivorous species feeding on plants in one or a few related plant families [44]. Herbivorous insects damage $18 \%$ of world agricultural production and this is mainly controlled by chemical methods [59]. Despite these damages, less than 0.5 percentage of the total number of the known insect species are considered pests. Aside from anthropocentric perception and societal prejudice, insects are not pests in an ecological or evolutionary context [30].

Insects are vital for human survival, because crops cannot be produced without the ecosystem functions provided by insects. Around $72 \%$ of the world's crops are dependent on insects for pollination [35]. Pollinating insects improve or stabilize the yield of three-quarters of all crop types globally-one-third of global crop production by volume [60]. A variety of insect taxa have been linked with increasing seed set [19]. Insect pollinators includes hundreds of species of solitary bees, bumblebees, flies, beetles and butterflies, and in several crops, wild bee species are more important for pollination than the honeybee, Apis mellifera [61]. Globally pollination services by insects are estimated to contribute $9.5 \%$ to 
yield of crop production [62].

Pest control is an inevitability in agriculture. Predatory insects contribute significant ecosystem functions by controlling pest insects in cultivated crops. It was indicated in $75 \%$ of field studies that generalist predators reduce pest populations in arable farmland significantly [63], with ground beetles being dominant generalist predators in arable crops [24] and effectively reducing population sizes of economically significant agricultural pests such as aphids, slugs, root feeding flies and phytophagous beetles [64].

Insects are also important in improving agricultural soil. Through their activity in the soil, dung beetles increase nitrogen, phosphorous, potassium, calcium and magnesium or total proteins content which significantly elevate the yield of wheat plants relative to chemical fertilizers [11].

\section{Effect of Human Induced Habitat Change on Insect Functional Diversity}

Natural ecosystems are complex systems with diverse interactions. In agriculture, complex natural ecosystems are converted to simplified managed ecosystems and the intensification of resource use, including applications of more agrochemicals and a generally higher input and output [5]. These systems are open systems where energy is lost and therefore need continued costly external inputs. This is in contrast with natural ecosystems that are closed systems, where energy is recycled within the system, eliminating the need for external inputs. In agricultural ecosystems the important ecosystem functions, mostly provided by insects, are systematically removed. Insect pests are created through the manipulation of habitats by humans, where crops are selected for larger size, higher yields, nutritious value, and are cultivated in monocultures for maximum production. Monocultures essentially create "biological deserts" where only a limited number of species can survive. In addition, monocultures provide a highly favourable environment for the population increase of certain herbivorous insects. These herbivorous insects are also capable of evolving to biotypes that can adapt to new situations, for example, overcome the effect of toxic materials, such as pesticides, or bypass natural or artificial plant resistance. When using pesticides natural predators are killed in the process, leaving no control for the population growth of the herbivorous insects. Ecosystem functions are further decreased by chemical fertilizers. Overuse of nitrogen fertilizer enables a few plant species to thrive, while the majority of plant species that have symbiotic relationships with insects disappear from the system [60].

The intensification of agricultural production systems in combination with high agrochemical input in crop fields, are the primary causes for the rapid decrease of biodiversity [65]. The loss of this agricultural biodiversity have both financial and social risk, as well as lasting effects on agricultural productivity, impacting food security in the long term. Continued sustainable land use in unpredictable and changing environments is only possible with conservation of max- 
imum biodiversity [5]. A shift to sustainable agriculture will require changes in production methods that will enhance diversity in farming systems.

\section{Conclusion}

With most of the world's fertile land being used for agriculture and arable land areas that cannot be expanded further we are running out of options to ensure food security for a growing population. The only option left is to use the existing land more sustainably. In this regard insects can provide the necessary solutions. Insects, as major contributors to ecosystem function on all levels, perform critical functions in any ecosystem. We need to manage agricultural systems in such a way that insects performing valuable ecosystem services form a fundamental part of the system. Diversity in terms of species is just one of many possible ways of describing communities and there are other aspects when considering a community such as the size and ecological role of the most abundant species, as well as the interaction between different groups and the structure of the community. Biodiversity should not be viewed as only an add-on, but it should be viewed as an integral part in our agricultural ecosystems and of paramount importance for our future food security. Future research in sustainable agriculture should therefore focus on the role of insects in ecosystems. By understanding the important functions of insects in natural ecosystems their value in agricultural systems can be realized. With a knowledge of ecosystem functions provided by insects we can then accommodate these insects in agricultural systems by changing the management practices to increase the functional diversity in these systems.

\section{References}

[1] FAO (2006) World Agriculture: Towards 2030/2050. Prospects for Food, Nutrition, and Major Commodity Groups. Food and Agricultural Organisation, Global Perspectives Study Unit, Rome.

[2] Godfray, H.C.I. and Garnett, T. (2014) Food Security and Sustainable Intensification. Philosophical Transactions of the Royal Society B: Biological Sciences, 369 20120273. https://doi.org/10.1098/rstb.2012.0273

[3] Sandhu, H., Wratten, S.D., Costanza, R., Pretty, J., Porter, J.R. and Regenold, J. (2015) Significance and Value of Non-Traded Ecosystem Services on Farmland. Peer Journal, 3, e762. https://doi.org/10.7717/peerj.762

[4] Sparks, T.C. and Nauen, R. (2015) IRAC: Mode of Action Classification and Insecticide Resistance Management. Pesticide Biochemistry and Physiology, 121, 122-128. https://doi.org/10.1016/j.pestbp.2014.11.014

[5] Tscharntke, T., Klein, A.M. Kruess, A., Steffan-Dewenter, I. and Thies, C. (2005) Landscape Perspectives on Agricultural Intensification and Biodiversity-Ecosystem Service Management. Ecology Letters, 8, 857-874. https://doi.org/10.1111/j.1461-0248.2005.00782.x

[6] Pimentel, D. (2017) Pest Control in World Agriculture. Encyclopedia of Life Support Systems (EOLSS), 2.

[7] Pimentel, D., Lach, L., Zuniga, R. and Morrison, D. (2000) Environmental and 
Economic Costs of Nonindigenous Species in the United States. BioScience, 50, 53-65. https://doi.org/10.1641/0006-3568(2000)050[0053:EAECON]2.3.CO;2

[8] Pywell, R.F., Heard, M.S., Woodcock, B.A., et al. (2015) Wildlife Friendly Farming Increases Crop Yield: Evidence for Ecological Intensification. Proceedings of the Royal Society B, 282, 2015-1740. https://doi.org/10.1098/rspb.2015.1740

[9] Daily, G.C. (1997) What Are Ecosystem Services? In: Daily, G., Ed., Natures Services: Societal Dependence on Natural Ecosystems. Island Press, Washington DC, $1-10$.

[10] Fincher, G.T., Monson, W.G., and Burton G.W. (1981) Effects of Cattle Faeces Rapidly Buried by Dung Beetles on Yield and Quality of Coastal Bermudagrass. Agronomy Journal, 73, 775-779. https://doi.org/10.2134/agronj1981.00021962007300050007x

[11] De Groot, R.S., Wilson. M.A. and Boumans, R.M.J. (2002) A Typology for the Classification, Description and Valuation of Ecosystem Functions, Goods and Services. Ecological Economics, 41, 393-408. https://doi.org/10.1016/S0921-8009(02)00089-7

[12] Nichols, E., Spector, S., Louzada, J., Larsen, T., Amezquita, S. and Favila, M.E. (2008) Ecological Functions and Ecosystem Services Provided by Scarabaeinae Dung Beetles. Biological Conservation, 141, 1461-1474. https://doi.org/10.1016/j.biocon.2008.04.011

[13] Gabriel, D. and Tscharntke, T. (2006) Insect Pollinated Plants Benefit from Organic Farming. Agriculture Ecosystems \& Environment, 118, 43-48.

https://doi.org/10.1016/j.agee.2006.04.005

[14] Slade, E.M., Riutta, T., Roslin, T. and Tuomisto, H.L. (2016) The Role of Dung Beetles in Reducing Greenhouse Gas Emissions from Cattle Farming. Scientific Reports, 6, Article No. 18140.

[15] Landis, D.A., Wratten, S.D. and Gurr, G.M. (2000) Habitat Management to Conserve Natural Enemies of Arthropod Pests in Agriculture. Annual Review of Entomology, 45, 175-201. https://doi.org/10.1146/annurev.ento.45.1.175

[16] Brewer, M.J. and Elliott, N.C. (2004) Biological Control of Cereal Aphids in North America and Mediating Effects of Host Plant and Habitat Manipulations. Annual Review of Entomology, 49, 219-242. https://doi.org/10.1146/annurev.ento.49.061802.123149

[17] Bell, J.R., Traugott, M., Sunderland, K.D., Skirvin D.J., Mead, A., Kravar-Garde, L., Reynolds, K., Fenion, J.S. and Symondson, W.O.C. (2008) Beneficial Links for the Control of Aphids: The Effects of Compost Applications on Predators and Prey. Journal of Applied Ecology, 45, 1266-1273. https://doi.org/10.1111/j.1365-2664.2008.01479.x

[18] Lonsdorf, E., Kremen, C., Ricketts, T., Winfree, R., Williams, N. and Greenleaf, S. (2009) Modelling Pollination Services across Agricultural Landscapes. Annals of Botany, 103, 1589-1600. https://doi.org/10.1093/aob/mcp069

[19] Hoehn, P., Tscharntke, T., Tylianakis, J.M. and Steffan-Dewenter, I. (2008) Functional Group Diversity of Bee Pollinators Increases Crop Yield. Proceedings of the Royal Society B: Biological Sciences, 275, 2283-2291. https://doi.org/10.1098/rspb.2008.0405

[20] Robertson, G.P. and Swinton, S.M. (2005) Reconciling Agricultural Productivity and Environmental Integrity: A Grand Challenge for Agriculture. Frontiers in Ecology and the Environment, 3, 38-46. https://doi.org/10.1890/1540-9295(2005)003[0038:RAPAEI]2.0.CO;2 
[21] Altieri, M.A. (1991) Increasing Biodiversity to Improve Insect Pest Management in Agro-Ecosystems. In: Hawksworth, D., Ed., The Biodiversity of Micro-Organisms and Invertebrates. Its Role in Sustainable Agriculture, CAB International, Wallingford, UK, 165-182.

[22] May, R.M. (1988) How Many Species Are There on Earth? Science, 241, 1441-1449. https://doi.org/10.1126/science.241.4872.1441

[23] Dirzo, R. and Raven, P.H. (2003) Global State of Biodiversity and Loss. Annual Review of Environment and Resources, 28, 137-167. https://doi.org/10.1126/science.241.4872.1441

[24] Woodcock, B.A., Harrower, C., Redhead, J., Edwards, M., Vanbergen, A.J., Heard, M.S., Roy, D.B. and Pywell, R.F. (2014) National Patterns of Functional Diversity and Redundancy in Predatory Ground Beetles and Bees Associated with Key UK Arable Crops. Journal of Applied Ecology, 51, 142-151. https://doi.org/10.1111/1365-2664.12171

[25] Straub, C.S., Finke, D.L. and Snyder, W.E. (2008) Are the Conservation of Natural Enemy Biodiversity and Biological Control Compatible Goals? Biological Control, 45, 225-237. https://doi.org/10.1016/j.biocontrol.2007.05.013

[26] Volker, H.W.R., Rasmussen, N.L., Dibble, C.J. and Van Allen, B.G. (2014) Resolving the Roles of Body Size and Species Identity in Driving Functional Diversity. Proceedings of the Royal Society B: Biological Sciences, 281, 2013-3203.

[27] Rudolf, V.H.W. and Rasmussen, N.L. (2013) Population Structure Determines Functional Differences among Species and Ecosystem Processes. Nature Communications, 4, Article No. 2318. https://doi.org/10.1016/j.biocontrol.2007.05.013

[28] Woodward, G., Blanchard, J., Lauridsen, R.B., Edwards, F.K., Jones, J.I., Figueroa, D., Warren, P.H., Petchey, O.L. and Guy, W. (2010) Individual-Based Food Webs: Species Identity, Body Size and Sampling Effects. Advances in Ecological Research, 43, 211-266. https://doi.org/10.1016/B978-0-12-385005-8.00006-X

[29] Gilljam, D., Edwards, F.K., Thierry, A., et al. (2011) Seeing Double: Size-Based and Taxonomic Views of Food Web Structure. Advances in Ecological Research, 45, 67-133. https://doi.org/10.1016/B978-0-12-386475-8.00003-4

[30] Kim, K.C. (1993) Biodiversity, Conservation and Inventory: Why Insects Matter. Biodiversity \& Conservation, 2, 191-214. https://doi.org/10.1007/BF00056668

[31] Samways, M.J. (1993) Insects in Biodiversity Conservation: Some Perspectives and Directives. Biodiversity \& Conservation, 2, 258-282. https://doi.org/10.1007/BF00056672

[32] Stork, N.E., McBroom, J., Gely, C. and Hamilton, A.J. (2015) New Approaches Narrow Global Species Estimates for Beedtles, Insects, and Terrestrial Arthropods. Proceedings of the National Academy of Sciences of the United States of America, 112, 7519-7523. https://doi.org/10.1073/pnas.1502408112

[33] Zhang, Z.Q. (2011) Animal Biodiversity: An Introduction to Higher-Level Classification and Taxonomic Richness. Zootaxa, 3148, 7-12.

[34] Samways, M.J. (2005) Insect Diversity Conservation. Cambridge University Press, New York, 25-29. https://doi.org/10.1017/CBO9780511614163

[35] Dicke, M. (2017) Ecosystem Services of Insects. In: Van Huis, A. and Tomberlin, J.K., Eds., Insects as Food and Feed: From Production to Consumption, Wageningen Academic Publishers, Wageningen, The Netherlands, 61-76.

[36] Farrell, B.D. (1998) "Inordinate Fondness" Explained: Why Are There So Many Beetles? Science, 281, 555-559. https://doi.org/10.1126/science.281.5376.555 
[37] Hunt, T., Bergsten, J., et al. (2007) A Comprehensive Phylogeny of Beetles Reveals the Evolutionary Origins of a Superradiation. Science, 318, 1913-1916. https://doi.org/10.1126/science.1146954

[38] Naeem, S., Duffy, J.E. and Zavaleta, E. (2012) The Functions of Biological Diversity in an Age of Extinction. Science, 336, 1401-1406. https://doi.org/10.1126/science.1215855

[39] Gullan, P.J. and Cranston, P.S. (2010) The Insects: An Outline of Entomology. Blackwell Publishing, Hoboken, NJ, 584 p.

[40] Mattson, W.J. and Addy, N.D. (1975) Phytophagous Insects as Regulators of Forest Primary Production. Science, 190, 515-522. https://doi.org/10.1126/science.190.4214.515

[41] Belovsky, G.E. and Slade, J.B. (2000) Insect Herbivory Accelerates Nutrient Cycling and Increases Plant Production. Proceedings of the National Academy of Sciences of the United States of America, 97, 14412-14417. https://doi.org/10.1073/pnas.250483797

[42] Hunter, M.D. (2001) Insect Population Dynamics Meets Ecosystem Ecology: Effects of Herbivory on Soil Nutrient Dynamics. Agricultural and Forest Entomology, 3, 77-84. https://doi.org/10.1046/j.1461-9563.2001.00100.x

[43] Metcalfe, D.B., Asner, G.P., Martin, R.E., Silva Espejo, J.E., Huaraca Huasco, W., Farfan Amezquita, F.F., Carranza-Jimenez, L., Galiano Cabrera, D.F., Durand Baca, L., Sinca, F., et al. (2014) Herbivory Makes Major Contributions to Ecosystem Carbon and Nutrient Cycling in Tropical Forests. Ecology Letters, 17, 324-332. https://doi.org/10.1111/ele.12233

[44] Schoonhoven, L.M., Van Loon, J.J.A. and Dicke, M. (2005) Insect-Plant Biology. Oxford University Press, Oxford, UK, 400 p.

[45] Van Lenteren, J.C. (2012) Internet Book of Biological Control. International Organization for Biological Control, Zürich, Switzerland. http://tinyurl.com/zk3rdrr

[46] Scholtz, C.H. and Mansell, M.W. (2009) Insect Biodiversity in the Afrotropical Region. In: Foottit, R. and Adler, P., Eds., Insect Biodiversity: Science and Society, Blackwell Publishing, Hoboken, NJ, 69-82. https://doi.org/10.1002/9781444308211.ch5

[47] Macfadyen, S., Kramer, E.A., Parry, H.R. and Schellhorn, N.A. (2015) Temporal Change in Vegetation Productivity in Grain Production Landscapes: Linking Landscape Complexity with Pest and Natural Enemy Communities. Ecological Entomology, 40, 56-69. https://doi.org/10.1111/een.12213

[48] Evans, T.A., Dawes, T.Z., Ward, P.R. and Lo, N. (2011) Ants and termites Increase Crop Yield in Dry Climate. Nature Communications, 2, Article No. 262.

https://doi.org/10.1038/ncomms1257

[49] Merritt, R.W. and De Jong, G.D. (2015) Arthropod Communities in Terrestrial Environments. In: Benbow, M.E., Tomberlin, J.K. and Tarone, A.M., Eds., Carrion Ecology, Evolution, and Their Applications, CRC Press, Boca Raton, FL, 65-91.

[50] Farwig, N., Brandl, R., Siemann, S., Wiener, F. and Muller, J. (2014) Decomposition Rate of Carrion Is Dependent on Composition Not Abundance of the Assemblages of Insect Scavengers. Oecologia, 175, 1291-1300. https://doi.org/10.1007/s00442-014-2974-y

[51] Richards, E.N. and Goff, M.L. (1997) Arthropod Succession on Exposed Carrion in Three Contrasting Tropical Habitats on Hawaii Island, Hawaii. Journal of Medical Entomology, 34, 328-339. https://doi.org/10.1093/jmedent/34.3.328 
[52] Mascaro, J. (2013) Origins of the Novel Ecosystems Concept. In: Hobbs. R., Hall, C.M., et al., Eds., Novel Ecosystems. Intervening in the New Ecological World Order, Wiley-Blackwell, Hoboken, NJ, 45-57. https://doi.org/10.1002/9781118354186.ch5

[53] Pearce, F. (2016) The New Wild-Why Invasive Species Will Be Nature's Salvation. Icon Books Ltd., UK.

[54] Schlaepfer, M.A., Sax, D.F. and Olden, J.D. (2011) The Potential Conservation Value of Non-Native Species. Conservation Biology, 25, 428-437. https://doi.org/10.1111/j.1523-1739.2010.01646.x

[55] DeBach, P. (1964) Biological Control of Insect Pests and Weeds. Cambridge University Press, Cambridge, UK, 844 p.

[56] Cock, M.J.W., Murphy, S.T., Kairo, M.T.K., Thompson, E., Murphy, R.J. and Francis, A.W. (2016) Trends in the Classical Biological Control of Insect Pests by Insects: An Update of the BIOCAT Database. BioControl, 61, 349-363. https://doi.org/10.1007/s10526-016-9726-3

[57] Davis, A.L.V. (1996) Seasonal Dung Beetle Activity and Dung Dispersal in Selected South African Habitats: Implications for Pasture Improvement in Australia. Agriculture, Ecosystems and Environment, 58, 157-169. https://doi.org/10.1016/0167-8809(96)01030-4

[58] Tyndalebiscoe, M. and Vogt, W.G. (1991) Effects of Adding Exotic Dung Beetles to Native Fauna on Bush Fly Breeding in the Field. Entomophaga, 36, 395-401. https://doi.org/10.1007/BF02377944

[59] Losey, J.E. and Vaughan, M. (2006) The Economic Value of Ecological Services Provided by Insects. BioScience, 56, 311-323. https://doi.org/10.1641/0006-3568(2006)56[311:TEVOES]2.0.CO;2

[60] Schwägerl, C. (2016) What's Causing the Sharp Decline in Insects, and Why It Matters. Yale Environment 360, 6 July 2016.

[61] Garibaldi, L.A., Steffan-Dewenter, I., Winfree, R., Aizen, M.A., et al. (2013) Wild Pollinators Enhance Fruit Set of Crops Regardless of Honey Bee Abundance. Science, 339, 1608-1611. https://doi.org/10.1126/science.1230200

[62] Gallai, N., Salles, J.M., Settele, J. and Vaissiere, B.E. (2009) Economic Valuation of the Vulnerability of World Agriculture Confronted with Pollinator Decline. Ecological Economics, 68, 810-821. https://doi.org/10.1016/j.ecolecon.2008.06.014

[63] Symondson, W.O.C., Sunderland, K.D. and Greenstone, M.H. (2002) Can Generalist Predators Be Effective Biocontrol Agents? Annual Review of Entomology, 47, 561-594. https://doi.org/10.1146/annurev.ento.47.091201.145240

[64] Kromp, B. (1999) Carabid Beetles in Sustainable Agriculture: A Review on Pest Control Efficacy, Cultivation Impacts and Enhancement. Agriculture, Ecosystems \& Environment, 74, 187-228. https://doi.org/10.1016/S0167-8809(99)00037-7

[65] Robinson, R.A. and Sutherland, W.J. (2002) Post-War Changes in Arable Farming and Biodiversity in Great Britain. Journal of Applied Ecology, 39, 157-176. https://doi.org/10.1046/j.1365-2664.2002.00695.x 